\title{
Recombinant Protein
}

National Cancer Institute

\section{Source}

National Cancer Institute. Recombinant Protein. NCI Thesaurus. Code C17081.

Proteins produced by genes or recombinant DNA that has been artificially engineered and inserted into a heterologous host. Recombinant proteins are used extensively by investigators of disease pathways to identify protein targets for potential drug therapies. 